\title{
Penyesuaian Dosis Obat Berdasarkan Nilai Kreatinin Klirens pada Pasien Geriatri Rawat Inap di RSUP Dr. Kariadi Semarang, Indonesia
}

\author{
Drug Dosage Adjustment based on Creatinin Clirens in Hospitalized Geriatric \\ Patients in RSUP dr. Kariadi Semarang, Indonesia
}

Noor Haryati, Fita Rahmawati*, Djoko Wahyono

Magister Farmasi Klinik, Fakultas Farmasi, Universitas Gadjah Mada

Corresponding author: Fita Rahmawati: Email: malihahanun@yahoo.com

Submitted: 01-06-2019 Revised:12-06-2019 Accepted: 12-06-2019

\begin{abstract}
ABSTRAK
Pasien geriatri biasanya mengalami multipathology dan polypharmacy yang dapat mengakibatkan munculnya respon yang berlebihan seperti efek samping bahkan efek toksik. Untuk menghindari hal ini diperlukan penyesuaian dosis berbasis farmakokinetika individual. Penelitian ini bertujuan untuk melihat persentase obat yang membutuhkan adjustment dose pada pasien geriatri berdasarkan kreatinin klirens ginjal yang diukur dengan formula Cockroft-Gault dan menganalisa hubungan ketepatan pendosisan dengan outcome clinic. Penelitian dilakukan dengan rancangan cross-sectional dengan pengambilan data secara retrospektif melalui penelusuran data rekam medis pasien geriatri rawat inap yang dirawat di RSUP dr. Kariadi Semarang tahun 2017. Data yang diamati adalah regimen pengobatan, serum kreatinin, outcome clinic dan adverse drug reaction yang terjadi. Selanjutnya dilakukan estimasi kreatinin kliren yang dilanjutkan dengan menilai kesesuaian dosis dengan referensi dan formula Giusti Hayton. Analisis data dilakukan secara deskriptif dan uji Chi-square dengan SPSS untuk menganalisa pengaruh penyesuaian dosis dengan clinical outcome. Hasil penelitian menunjukkan dari 100 rekam medis pasien yang memenuhi inklusi terdapat 99 pasien yang mendapatkan obat dan memerlukan penyesuaian dosis. Pasien yang mendapatkan regimen pengobatan tepat sebesar 73\%. Dari 785 obat yang diresepkan, $353(44,97 \%)$ obat memerlukan penyesuaian dosis. Dari obat-obat yang memerlukan penyesuaian dosis tersebut $322(91,22 \%)$ sudah tepat dan 31 (8,78 \%) belum tepat. Obat-obat yang belum tepat dosis adalah ketorolak injeksi, ranitidin injeksi dan beberapa jenis antibiotik (meropenem injeksi, levofloksasin tablet, dan sefiksim tablet). Tidak ada hubungan yang bermakna antara ketepatan dosis dengan outcome clinic $(\mathrm{p}=0,289)$.
\end{abstract}

Kata kunci: geriatri, kreatinin klirens, penyesuaian dosis, outcome clinic.

\begin{abstract}
Geriatric patients usually experience multipathology and polypharmacy which can lead to excessive responses such as side effects and even toxic effects. To avoid this it is necessary to adjust the dose based on individual pharmacokinetics. This study aims to look at the persentage of drugs that require adjustment doses in geriatric patients based on renal creatinine measured by the Cockroft-Gault formula and analyze the relationship of exact dosing with clinical outcome. The study was conducted with a cross-sectional design with retrospective retrieval of data through tracing medical records of inpatient geriatric patients who were treated at RSUP dr. Kariadi Semarang in 2017. The data observed were treatment regimens, serum creatinine, clinical outcome and adverse drug reaction that occurred. Furthermore, the estimated creatinine clearance was followed by assessing the suitability of the dose with the reference and formula Giusti Hayton. Data analysis was carried out descriptively and Chi-square test with SPSS to analyze the effect of dose adjustment with clinical outcomes. The results showed that out of 100 medical records of patients who fulfilled the inclusion there were 99 patients who received the drug and needed a dose adjustment. Patients who received the right treatment regimen were $73 \%$. Of the 785 prescribed drugs, $353(44.97 \%)$ drugs required a dose adjustment. Of the drugs that require a dose adjustment, $322(91.22 \%)$ are correct and $31(8.78 \%)$ are not correct. Drugs that have not been properly dosed are ketorolac injection, ranitidine injection and several types of antibiotics (meropenem injection, levofloxacin tablets, and
\end{abstract}


cefixime tablets). There was no significant relationship between the accuracy of the dose and the clinic outcome $(\mathrm{p}=0.289)$.

Keywords: geriatrics, creatinine clearance, dose adjustment, clinical outcome.

\section{PENDAHULUAN}

Salah satu perubahan yang sering terjadi seiring dengan proses penuaan adalah penurunan fungsi ginjal. Hal ini disebabkan oleh perubahan faktor anatomis, fisiologis dan klinis. Masa ginjal semakin menurun dan pada usia 70 tahun sekitar 30-50 \% jaringan glomerulus kortikal telah hilang. Untuk setiap dekade diatas usia 40 tahun, Glomerular Filtration Rate (GFR) menurun sekitar $10 \mathrm{ml} /$ menit sehingga pada usia 70 tahun GFR telah menurun sekitar 30 $\mathrm{ml} /$ menit. Penurunan fungsi ginjal pada penuaan ini bersifat irreversible (Chan dkk., 2014). Proses penuaan juga diperparah oleh faktor klinis yang menjadi faktor resiko terjadinya penyakit gangguan ginjal. Faktor klinis yang dimaksud adalah penyakit kronis yang diderita seperti hipertensi, diabetes, hiperlipidemia, penyakit kardio vaskuler, dll (Mallappallil dkk., 2014).

Beberapa penelitian sebelumnya menunjukkan penyesuaian dosis pada pasien lanjut usia belum sepenuhnya dilakukan. Penelitian yang dilakukan oleh Alahdal (2011) menunjukkan dari 502 obat yang diteliti, 196 (39\%) memerlukan penyesuaian dosis dimana $92(46,9 \%)$ sudah diberikan penyesuaian dosis dan $104(53,1 \%)$ belum diberikan penyesuaian dosis. Penelitian lain dilakukan oleh Praptiwi (2017) menunjukkan $21 \%$ pasien mendapatkan obat dengan tepat dosis dan $79 \%$ tidak tepat dosis. Dari 184 kasus pengobatan yang diteliti 42,39\% diberikan dengan tepat dosis dan 57,61 $\%$ tidak tepat dosis. Pada tahun 2006 KDIGO (Kidney Disease: Improving Global Outcomes) menyarankan pemeriksaan kreatinin pada pasien usia diatas 60 tahun terutama pada pasien yang memiliki faktor resiko penyakit ginjal (Mallappallil dkk., 2014). Penghitungan kreatinin klirens diperlukan untuk mengetahui apakah pasien mengalami penurunan fungsi ginjal, serta bagaimana regimen obat yang tepat untuk memperoleh tujuan terapi yang direncanakan. Pada pasien geriatri penurunan fungsi ginjal seringkali tidak terlihat karena tertutup oleh nilai serum kreatinin yang normal. Tetapi setelah dilakukan penghitungan nilai kreatinin klirens terlihat bahwa kemampuan fungsi ekskresi pada ginjal sudah mengalami penurunan.
Untuk obat-obat yang larut dalam air (hidrosoluble), menurunnya laju filtrasi glomerulus akan berdampak obat lama berada di tubuh. Akibatnya dapat terjadi Adverse Drug Reaction (ADR) terutama obat yang diekskresi ginjal dalam bentuk utuh (unchanged) dengan nilai fraction excreted unchanged (f) $\geq 30 \%$ (LeaHenry dkk., 2018). Penelitian yang dilakukan oleh Corsonello (2005) menunjukkan bahwa terjadi ADR pada $\pm 30 \%$ pasien geriatric dengan gangguan fungsi ginjal yang tersembunyi. Upaya untuk menghindari munculnya ADR karena akumulasi obat di ginjal adalah menghindari penggunaan obat nefrotoksik dan penyesuaian dosis obat sesuai dengan klirens pasien (Montañés-Pauls dkk., 2009).

Tujuan dilakukan penelitian adalah mengidentifikasi prevalensi pasien geriatri yang mengalami penurunan fungsi ginjal sehingga memerlukan adjustment dosis dalam pengobatannya, mengidentifikasi kesesuaian dosis pada pengobatan pasien geriatri, dan menganalisis hubungan kesesuaian dosis terhadap outcome clinic. Hasil penelitian diharapkan dapat bermanfaat untuk Apoteker dan pembuat kebijakan di Rumah Sakit sehingga dapat memberikan jaminan pelayanan yang aman kepada pasien dan kerusakan ginjal yang lebih parah dapat dicegah.

\section{METODOLOGI \\ Rancangan Penelitian}

Penelitian ini bersifat observasional analitik dengan pendekatan cross sectional. Pengambilan sampel dilakukan secara retrospektif di RSUP dr Kariadi, Semarang.

\section{Subyek Penelitian}

Populasi penelitian adalah rekam medis pasien geriatri. Sejumlah 100 rekam medis pasien digunakan sebagai sampel dalam penelitian ini yang ditetapkan secara accidental sampling. Kriteria Inklusi yang digunakan adalah rekam medis pasien geriatri rawat inap yang dirawat pada tahun 2017di RSUP Dr. Kariadi, berusia $\geq 60$ tahun, data rekam medis lengkap (terdapat data serum kreatinin, berat dan tinggi badan pasien, regimen terapi). Pasien yang menjalani hemodialisa, pasien 
dengan masa perawatan $<48$ jam dieksklusi dari penelitian ini.

\section{Penghitungan Penyesuaian Dosis}

Tahap - tahap yang dilakukan dalam penyesuaian dosis obat sesuai fungsi ginjal adalah:

Menghitung estimasi Kreatinin klirens pasien dengan formula Cockroft Gault (Cockroft and Gault, 1976):

Laki-laki:

$$
\mathrm{CrCl}=\frac{(140-\text { usia }(\text { tahun })) x \text { Berat Badan }(\mathrm{kg})}{72+\text { Serum Creatinin }\left(\frac{\mathrm{mg}}{\mathrm{dl}}\right)}
$$

Perempuan:

$$
\mathrm{CrCl}=\frac{0,85 \times(140-\text { usia }(\text { tahun }) \times \text { Berat Badan }(\mathrm{kg})}{72+\text { Serum Kreatinin }\left(\frac{m g}{d l}\right)}
$$

Untuk pasien dengan total body weight (TBW) > $125 \%$ ideal body weight (IBW) maka adjusted body weight (ABW) dihitung dengan formula:

$$
\mathrm{ABW}=\mathrm{IBW}+0,4(\mathrm{TBW}-\mathrm{IBW})
$$

Dimana:

Laki-laki:

IBW $=50 \mathrm{~kg}+\{2,3 \times$ (tinggi badan (inch)-60) $\}$

Perempuan:

$\mathrm{IBW}=45,5 \mathrm{~kg}+\{2,3 \times($ tinggi badan $($ inch $)-60)\}$

Menilai kesesuaian dosis yang diberikan pasien. Kesesuaian dosis pemberian obat dinilai berdasarkan:

Dosis penyesuaian obat pada literatur Drug Information Handbook (DIH) edisi 22 th 2014 dan Renal Pharmacoterapy (2013).

Formula Giusti Hayton, mengunakan fraksi obat yang diekskresikan dalam bentuk utuh (f) sebagai berikut (Shargel dkk.,2005):

$$
\mathrm{G}=\frac{\mathrm{K}^{\mathrm{U}}}{\mathrm{K}^{\mathrm{N}}}=1-f\left(1-\frac{C L_{R}^{U}}{C L_{R}^{N}}\right)
$$

Dosis penyesuaian $=\mathrm{G} \times$ Dosis normal

dimana, G: faktor Giusti Hayton; F: fraksi obat yang diekskresi "unchanged" melalui urin; $\mathrm{CL}^{\mathrm{U}}$ : Kliren kreatinin pasien gangguan ginjal; $\mathrm{CL}^{\mathrm{N}}$ : Kliren kreatinin normal; $\mathrm{K}^{\mathrm{U}}$ : tetapan kecepatan eliminasi pasien gangguan ginjal; $\mathrm{K}^{\mathrm{N}}$ : tetapan kecepatan eliminasi normal.
Menghitung estimasi kadar obat di dalam darah dengan perhitungan Cmax dan Cmin. Hasil perhitungan ini digunakan untuk mengetahui apakah dosis yang digunakan masuk dalam kisaran terapi sehingga outcome clinic dapat tercapai. Formula untuk menghitung Cmax dan Cmin adalah sebagai berikut:

$$
\begin{gathered}
\operatorname{Cmax}^{\mathrm{ss}}=\frac{F x D x e^{-k t m a x^{s s}}}{V d\left(1-e^{-k \mathrm{\tau}}\right)} \\
\mathrm{Cmin}^{\mathrm{ss}}=\operatorname{Cmax}^{\mathrm{ss}} \mathrm{x} e^{-k\left(\mathrm{\tau}-t m a x^{s s}\right)}
\end{gathered}
$$

dimana, $\mathrm{Cmax}^{\text {ss: }}$ kadar maksimum pada saat steady state; $\mathrm{Cmin}^{\text {ss: }}$ : kadar minimum pada saat steady state; F: ketersediaan obat; Vd: volume distribusi; K: tetapan eliminasi obat; $\mathrm{G}$ : interval pemberian obat (Wahyono, 2012)

\section{Observasi outcome clinic}

Observasi terhadap Outcome clinic meliputi target terapi yang harus dicapai (efektivitas) dan toksisitas/efek samping terapi. Target terapi untuk setiap indikasi terapi obat meliputi parameter klinis yang ditetapkan dalam referensi. Parameter klinis ditentukan untuk setiap kondisi medis seperti HbA1C untuk parameter diabetes, International Normalized Ratio (INR) untuk antikoagulan, dll (Nace dkk, 2012). Pada penelitian ini dilakukan pengamatan outcome clinic pada pasien baik yang mendapatkan pengobatan dengan dosis yang tepat atau tidak. Parameter klinis yang dicapai pada akhir perawatan diamati untuk melihat pengaruh terapi obat yang diberikan. ADR dan efek toksis yang muncul karena dosis berlebih juga diamati.

\section{Analisis Data}

Analisis data secara deskriptif dilakukan untuk mengetahui karakteristik pasien. Analisis statistik Chi-square digunakan untuk mengetahui hubungan ketepatan pendosisan terhadap outcome clinic.

\section{HASIL DAN PEMBAHASAN}

Karakteristik pasien geriatri (Tabel I). Umur pasien geriatri rata-rata $70 \pm 0,73$ tahun dengan jenis kelamin laki-laki $47 \quad \%$ dan perempuan $53 \%$. Hal ini sesuai dengan data Badan Pusat Statisitik Propinsi Jawa Tengah tahun 2017 yang menunjukkan bahwa usia harapan hidup mencapai 74,18 tahun pada tahun 2018. Usia ini mengalami peningkatan 
Tabel I. Karakteristik Pasien Geriatri di RSUP Dr. Karyadi, Semarang

\begin{tabular}{|c|c|c|}
\hline Karakteristik & $\begin{array}{c}\text { Jumlah pasien } \\
(n=100)\end{array}$ & $\begin{array}{c}\text { Rata - rata } \\
\pm \text { SD } \\
\end{array}$ \\
\hline \multicolumn{3}{|l|}{ Jenis kelamin } \\
\hline Laki-laki & 47 & \\
\hline Perempuan & 53 & \\
\hline Usia (tahun) & & $70 \pm 0.73$ \\
\hline $60-69$ & 63 & \\
\hline $70-79$ & 23 & \\
\hline$>80$ & 14 & \\
\hline \multicolumn{3}{|l|}{ Diagnosa utama } \\
\hline Infeksi & 39 & \\
\hline Kanker & 30 & \\
\hline Jantung & 11 & \\
\hline Infark Serebral & 7 & \\
\hline DM tipe 2 & 6 & \\
\hline Gagal ginjal & 3 & \\
\hline Hipertensi & 2 & \\
\hline Fraktur & 2 & \\
\hline Jumlah resep per pasien (obat) & & $8 \pm 0.41$ \\
\hline $1-4$ & 20 & \\
\hline$\geq 5$ & 80 & \\
\hline Nilai CrCl (ml/min) & & $38,15 \pm 0.66$ \\
\hline$>90$ & 0 & \\
\hline $60-89$ & 7 & \\
\hline $45-59$ & 23 & \\
\hline $30-44$ & 43 & \\
\hline $15-29$ & 22 & \\
\hline Length of stay (hari) & & $9 \pm 1.07$ \\
\hline$<4$ & 14 & \\
\hline $4-7$ & 28 & \\
\hline $8-14$ & 37 & \\
\hline $15-21$ & 17 & \\
\hline $22-30$ & 3 & \\
\hline$>30$ & 1 & \\
\hline \multicolumn{3}{|l|}{ Status pasien pulang } \\
\hline Hidup & 69 & \\
\hline Mati & 31 & \\
\hline
\end{tabular}

Keterangan: $\mathrm{CrCl}=$ Creatinin Cliren; $\mathrm{CHF}=$ Chronic Heart Failure; $\mathrm{DM}=$ Diabetes Mellitus; $\mathrm{COPD}=$ Chronic Obstructive Pulmonary Disease, $\mathrm{CKD}=$ Chronic Kidney Disease

dari 72,73 tahun pada tahun 2010. Jumlah penduduk lansia perempuan lebih tinggi dibandingkan laki-laki (8 penduduk lansia laki laki berbanding 10 penduduk lansia perempuan) (BPS, 2017).

Penyakit-penyakit yang umum diderita pasien geriatri meliputi kanker, Infeksi Pneumonia, Infark Cerebral, Congestive, Herat Failure, dan Diabetes Mellitus tipe 2. Menurut penelitian Hidayat (2015) penyakit yang diderita pasien geriatri rawat inap RSUP Dr Kariadi adalah: Community Acquired Pneumony (24,08\%) Chronic Heart Failure (9,85\%), Diabetes Mellitus (9,4\%), Chronic Kidney Disease /Acute Kidney Injury, Stroke Non Hemorrhage, Kanker masing-masing berjumlah 4,4\%.

Hasil estimasi klirens pasien dengan formula Cockroft-Gault menunjukkan bahwa mayoritas pasien geriatri mempunyai kliren kreatinin dibawah $50 \mathrm{ml} /$ menit. Menurunnya 
kreatinin klirens ginjal dapat dipengaruhi oleh beberapa hal seperti penuaan, penyakit degeneratif, obesitas dan penggunaan obatobatan yang dapat merusak ginjal (nefrotoksis) (Mallappallil dkk., 2014). Salah satu upaya yang dilakukan untuk memperlambat kerusakan ginjal lebih lanjut adalah dengan menghindari penggunaan obat-obat nefrotoksik atau penyesuaian dosis sesuai kemampuan fungsi ginjal. Bila $\mathrm{CrCl}<60 \mathrm{ml} / \mathrm{min}$ obat-obat tertentu tidak boleh diberikan terlalu lama karena tidak bisa dieliminasi oleh ginjal dalam jumlah cukup. Obat akan terakumulasi di dalam ginjal sebagai obat/metabolit aktif dan berakibat menimbulkan ADR dan bahkan menyebabkan toksisitas (Hartmann dkk., 2010).

Pada penelitian ini terdapat 787 obat diresepkan dan rata-rata pasien mendapatkan $8 \pm 0,41$ obat (rentang 2 - 16 obat) selama perawatan. Penggunaan $\geq 5$ obat dikatagorikan polifarmasi. Dampak polifarmasi dapat meningkatkan biaya obat dan ketidakpatuhan, meningkatkan ADR, interaksi obat, sindrom geriatri dan menurunnya kapasitas fungsional (Maher dkk, 2014).

Sejumlah $27 \quad \% \quad$ pasien geriatri menggunakan obat yang memerlukan penyesuain dosis. Dari 785 obat yang diresepkan terdapat $353 \quad(44,97 \%)$ obat memerlukan penyesuaian dosis. Obat yang diberikan dengan dosis yang tepat sejumlah 322 $(91,22 \%)$ dari jumlah obat yang perlu penyesuaian dosis $(n=353)$. Hasil penelitian menunjukkan bahwa ketidaksesuaian regimen pengobatan disebabkan karena: ketidaktepatan dosis, ketidaktepatan interval dan adanya kontra indikasi pada kreatinin kliren yang rendah (Tabel II).

Obat-obat yang belum tepat penyesuaian dosisnya adalah:

\section{Ketorolak injeksi}

Obat - obat Non Steroid Anti Inflamasi seperti ketorolak sering digunakan untuk mengatasi nyeri. Efek samping yang dapat muncul berupa perdarahan dan gangguan pada gastro intestinal. Kelompok usia geriatri beresiko mendapatkan efek samping tersebut. Disamping itu, resiko hiperkalemia dan hiponatremia dapat terjadi karena penghambatan prostaglandin ginjal. Ketorolak juga dapat meningkatkan Acute Kidney Disease terutama bila ada komorbid seperti hipertensi, diabetes dan Chronic Heart Failure (Chan dkk., 2014).

Ketorolak dengan $\mathrm{f}=60 \%$ memeerlukan penyesuaian dosis paa gangguan ginjal. Pada penelitian ini dosis ketorolak injeksi yang digunakan bervariasi, ada yang sudah tepat, tetapi ada pula yang belum tepat. Rata - rata digunakan selama 5 hari. Ketidaktepatan ditemukan pada pemakaian dosis $30 \mathrm{mg} / 8$ jam pada pasien dengan $\mathrm{CrCl} 10-50 \mathrm{ml} /$ menit. Menurut pustaka, dosis penyesuaian ketorolak adalah 7,5-15 mg/6 jam atau maksimal $60 \mathrm{mg} /$ hari (Lacy dkk, 2014 dan Golightly dkk, 2013), sedangkan dosis penyesuaian menurut formula Giusti Hayton adalah 7,5-20 mg/6 jam. Efek analgetik tercapai, tetapi pada satu kasus ditemukan peningkatan serum kreatinin dari 0.9 menjadi $1.4 \mathrm{ml} /$ menit yaitu pada pemakaian selama 12 hari. Efek samping berupa perdarahan dan nyeri gastro intestinal tidak terjadi dikarenakan digunakan bersama Ranitidin injeksi.

\section{Ranitidin injeksi}

H2 bloker digunakan secara luas untuk penyakit ulkus peptik, GERD (GastroEsophageal Reflux Disease) dan stress ulcer. Ranitidin injeksi diekskresi melalui ginjal dengan fraksi ekskresi 70\%. Dengan demikian, ada hubungan antara penurunan GFR dan farmakokinetik obat H2 Bloker. Pada Ranitidin kadar obat plasma meningkat $200 \%$ pada GFR $<30 \mathrm{ml} /$ menit dan meningkat $300 \%$ pada GFR $<20 \mathrm{ml} /$ menit bila dibandingkan dengan GFR normal. Resiko efek samping obat berupa perubahan mental status meningkat pada dosis yang tidak tepat, tetapi akan hilang bila obat dihentikan. Disamping itu resiko penggunaan antagonis reseptor H2 ini dapat menurunkan efektifitas pengikat fosfat (seperti : CaC03) dan menyebabkan pasien rentan terhadap infeksi nosokomial (Manlucu dkk., 2005).

Pada penelitian ini ditemukan penggunaan ranitidin injeksi yang belum tepat dosis, yaitu $50 \mathrm{mg} / 8$ jam pada $\mathrm{CrCl} 10-50$ $\mathrm{ml} /$ menit. Dosis penyesuaian ginjal adalah 50 mg / 18-24 jam (Lacy dkk, 2014) dan 25 mg/68 jam menurut formula Giusti Hayton. Ketidaktepatan dosis pada penelitian ini tidak memberikan efek samping yang dapat diamati dikarenakan digunakan dalam jangka pendek (rata-rata 5 hari). 
Tabel II. Daftar Obat-obat yang Belum Tepat Penyesuaian Dosis

\begin{tabular}{|c|c|c|c|c|c|c|}
\hline \multirow[b]{2}{*}{ Nama Obat } & \multirow{2}{*}{$\begin{array}{c}\begin{array}{c}\text { Jumlah } \\
\text { peresepan }\end{array} \\
\mathrm{N}(\%)\end{array}$} & \multirow[b]{2}{*}{$\begin{array}{c}\mathrm{CrCl} \\
(\mathrm{ml} / \mathrm{min})\end{array}$} & \multirow[b]{2}{*}{$\begin{array}{c}\text { Dosis } \\
\text { digunakan }\end{array}$} & \multicolumn{2}{|c|}{ Dosis Penyesuaian } & \multirow[b]{2}{*}{$\begin{array}{l}\text { Ket } \\
(*)\end{array}$} \\
\hline & & & & $\begin{array}{c}\text { DIH / Renal } \\
\text { Pharmacotherapy }\end{array}$ & $\begin{array}{l}\text { Formula } \\
\text { Giusty } \\
\text { Hayton }\end{array}$ & \\
\hline Ketorolak i,v & $6(1.7)$ & $10-50$ & $\begin{array}{l}30 \mathrm{mg} / 8 \\
\text { jam }\end{array}$ & 7,5-15 mg/6 jam & $\begin{array}{l}\text { 7,5 -20 } \\
\mathrm{mg} / 6 \text { jam }\end{array}$ & I \\
\hline Ranitidin i.v & $4(1.1)$ & $10-50$ & $\begin{array}{l}50 \mathrm{mg} / 8 \\
\mathrm{jam}\end{array}$ & 50 mg/18-24 jam & $\begin{array}{l}25 / 6-8 \\
\text { jam }\end{array}$ & I \\
\hline \multirow[t]{2}{*}{ Metformin p.o } & $3(0.8)$ & $<30$ & $\begin{array}{l}500 \mathrm{mg} / \\
12 \mathrm{jam}\end{array}$ & $\begin{array}{l}\text { Tidak } \\
\text { direkomendasi }\end{array}$ & $\begin{array}{l}175- \\
350 \mathrm{mg} / 12 \\
\text { jam }\end{array}$ & KI \\
\hline & & $30-45$ & $\begin{array}{l}500 \mathrm{mg} / 8 \\
\text { jam }\end{array}$ & $\begin{array}{l}250-500 \mathrm{mg} / 12 \\
\text { jam }\end{array}$ & $\begin{array}{l}\text { 200-450 } \\
\mathrm{mg} / \text { 8jam }\end{array}$ & I \\
\hline \multicolumn{7}{|l|}{ Antibakteri } \\
\hline Sefiksim p.o & $3(0.8)$ & $21-60$ & $\begin{array}{l}200 \mathrm{mg} / 12 \\
\text { jam }\end{array}$ & $260 \mathrm{mg} / 24$ jam & $\begin{array}{l}150 \mathrm{mg} / \\
12 \mathrm{jam}\end{array}$ & DI \\
\hline $\begin{array}{l}\text { Siprofloksasin } \\
\text { i.v }\end{array}$ & $3(0.8)$ & $10-50$ & $\begin{array}{l}400 \mathrm{mg} / 12 \\
\text { jam }\end{array}$ & $\begin{array}{l}200-300 \mathrm{mg} / 12 \\
\text { jam }\end{array}$ & $\begin{array}{l}250-300 \\
\mathrm{mg} / 12 \\
\text { jam }\end{array}$ & $\mathrm{D}$ \\
\hline $\begin{array}{l}\text { Levofloksasin } \\
\text { p.o }\end{array}$ & $2(0.6)$ & $10-50$ & $\begin{array}{l}500 \mathrm{mg} / 8 \\
\text { jam }\end{array}$ & $\begin{array}{l}\text { Inisial } 500 \mathrm{mg} \\
\text { lanjut } 250 \mathrm{mg} / 24 \\
\text { jam }\end{array}$ & $\begin{array}{l}500 \\
\mathrm{mg} / 24 \\
\text { jam }\end{array}$ & I \\
\hline \multirow[t]{2}{*}{$\begin{array}{l}\text { Meropenem } \\
\mathrm{I}, \mathrm{V}\end{array}$} & $2(0.6)$ & $>50$ & $1 \mathrm{~g} / 12 \mathrm{jam}$ & $1-2 \mathrm{~g} / 8 \mathrm{jam}$ & $\begin{array}{l}650- \\
1250 \mathrm{mg} / 8 \\
\text { jam }\end{array}$ & I \\
\hline & & 35 & $1 \mathrm{~g} / 8 \mathrm{jam}$ & 0,5-2 g/12 jam & $\begin{array}{l}0,25-1 \mathrm{~g} / \\
8 \text { jam }\end{array}$ & I \\
\hline $\begin{array}{l}\text { Ampisilin } \\
\text { sulbaktam i.v }\end{array}$ & $1(0.3)$ & 25 & 1,5 g/8jam & $1,5-3 \mathrm{~g} / 12 \mathrm{jam}$ & $\begin{array}{l}0,6-1,1 \\
\text { g/ } 8 \text { jam }\end{array}$ & I \\
\hline Cefepim i.v & $1(0.3)$ & 25 & $1 \mathrm{~g} / 8$ jam & $1-2 \mathrm{~g} / 24$ jam & $\begin{array}{l}200-750 \\
\mathrm{mg} / 8 \text { jam }\end{array}$ & I \\
\hline \multicolumn{7}{|l|}{ Diuretik } \\
\hline $\begin{array}{l}\text { Spironolakton } \\
\text { p.o }\end{array}$ & $1(0.3)$ & 16,47 & $\begin{array}{l}25 \mathrm{mg} / 24 \\
\text { jam }\end{array}$ & $\begin{array}{l}\text { Tidak } \\
\text { direkomendasi }\end{array}$ & $\begin{array}{l}10-20 \\
\mathrm{mg} / 24 \\
\text { jam }\end{array}$ & $\mathrm{KI}$ \\
\hline Mannitol i.v & $1(0.3)$ & 25 & $25 \mathrm{~g} / 6 \mathrm{jam}$ & Kontra indikasi & $\begin{array}{l}4,5-17,5 \\
g / 6 \text { jam }\end{array}$ & KI \\
\hline $\begin{array}{l}\mathrm{Na} \text { Fonda- } \\
\text { parinux s.c }\end{array}$ & $1(0.3)$ & 29,5 & $\begin{array}{l}2,5 \mathrm{mg} / 24 \\
\text { jam }\end{array}$ & Kontra indikasi & $\begin{array}{l}1,1 \mathrm{mg} / 24 \\
\text { jam }\end{array}$ & KI \\
\hline $\begin{array}{l}\text { Telbivudin } \\
\text { p.o }\end{array}$ & $1(0.3)$ & 37,80 & $\begin{array}{l}600 \mathrm{mg} / 24 \\
\text { jam }\end{array}$ & 600 mg/48 jam & $\begin{array}{l}450 \\
\mathrm{mg} / 24 \\
\text { jam }\end{array}$ & I \\
\hline Loratadin p.o & $2(0.6)$ & $<30$ & $\begin{array}{l}10 \mathrm{mg} / 12 \\
\text { jam }\end{array}$ & $10 \mathrm{mg} / 24$ jam & $\begin{array}{l}8 \mathrm{mg} / 24 \\
\text { jam }\end{array}$ & I \\
\hline
\end{tabular}

Keterangan: DIH: Drug Information Handbook edisi 22,2014; i.v: intra vena; p.o: peroral; s.c: sub cutan; $\mathrm{CrCl}$ : Kliren Kreatinin yang dihitung dengan formula Cockroft-Gault; I: tidak tepat interval; D: tidak tepat Dosis; DI : tidak tepat dosis dan interval; KI: tidak tepat karena kontra indikasi; $\left(^{*}\right)$ : ketidaksesuaian dibandingkan Pustaka DIH/Renal Pharmacotherapy 


\section{Metformin}

Metformin digunakan untuk menururunkan kadar gula darah terutama pada pasien DM dengan obesitas. Penggunaan Metformin dikontraindikasikan pada GFR $<30$ $\mathrm{ml} /$ menit, sedang pada GFR 30-45 $\mathrm{ml} /$ menit dapat digunakan dengan dosis yang disesuaikan. Masalah utama yang dapat terjadi berupa akumulasi metformin yang menyebabkan Lactat Acidosis (LA). LA dapat terjadi bila konsentrasi plasma metformin $>20 \mathrm{mg} / \mathrm{L}$ dan berakibat fatal bila mencapai $50 \mathrm{mg} / \mathrm{L}$. Range terapetik kadar plasma Metformin berkisar 0.3-1 mg/L, dengan kadar palung $0.7 \mathrm{mg} / \mathrm{L}$. Metformin diekskresi 90 $\%$ melalui ginjal dalam bentuk utuh berkorelasi dengan GFR. Pada banyak kasus, pemakaian Metformin diikuti dengan kenaikan serum kreatinin (SCr) (Heaf, 2014).

Pada penelitian ini, hasil perhitungan estimasi kadar plasma metformin pada $\mathrm{CrCl}<30$ $\mathrm{ml} /$ menit masih dalam range terapi $(0,45 \mathrm{mg} / \mathrm{L})$ sehingga tidak terjadi LA. Efek samping toksisitas metformin berupa muntah dan diare tidak teramati dikarenakan penggunaan metformin dibarengi dengan omeprazole atau ranitidin. Pada kasus ini terlihat peran Farmasi klinis merekomendasikan penghentian metformin dikarenakan kontra indikasi dengan $\mathrm{CrCl}$ pasien.

Pada pasien dengan $\mathrm{CrCl} 30-45 \mathrm{ml} /$ menit, pendosisan Metformin belum tepat. Dosis metformin digunakan $500 \mathrm{mg} / 8$ jam. Dosis penyesuaian menurut pustaka $250-500 \mathrm{mg} / 12$ jam (Lacy dkk,2014 dan Golightly dkk, 2013) dan 200-450 mg/8 jam menurut formula Giusti Hayton. Peningkatan serum kreatinin berkisar $0.5 \mathrm{mg} / \mathrm{L}$ terjadi pada satu kasus pasien, sehingga Metformin dihentikan.

\section{Antibakteri}

Quinolon

Quinolon termasuk Concentration

Dependent Killers. Antibiotik ini memberikan efek bakterisidal tergantung konsentrasi obat plasma. Penyesuaian dosis dilakukan dengan memperpanjang interval pemberian obat dan mempertahankan kadar plasma tetap diatas Minimal Inhibitary Concentration (MIC). Quinolon dapat menyebabkan cedera ginjal akut melalui reaksi hipersensitivitas akut, menghambat System Renin Angiotention, meningkatkan tekanan intraglomerulus dan meningkatkan serum kreatinin (Eyler dan Shvets, 2019).
Siprofloksasin merupakan antibiotik golongan Quinolon yang sering digunakan. Pada penelitian ini Ciprofloksasin yang diberikan tidak tepat dosis. Dosis yang digunakan 400 mg/12 jam, sedangkan dosis penyesuaian menurut Lacy dkk (2014) dan Golightly dkk (2013) pada $\mathrm{CrCl} 10-50 \mathrm{ml} / \mathrm{menit}$ adalah 200$300 \mathrm{mg} / 12$ jam, dan menurut formula Giusti Hayton 250-300 mg/12 jam. Outcome clinic tercapai pada kasus ini. Efek samping seperti diare headache, nausea tidak terjadi. Kenaikan SCr tidak dapat diamati karena tidak ada pemeriksaan SCr setelah penggunaan obat.

Levofloksasin digunakan tidak tepat interval pada penelitian ini. Dosis yang digunakan $500 \mathrm{mg} / 8$ jam, sedangkan dosis penyesuaian menurut pustaka adalah $500 \mathrm{mg}$ pada dosis inisial dilanjutkan $250 \mathrm{mg} / 24$ jam (Lacy dkk,2014 dan Golightly dkk, 2013). Dosis penyesuaian menurut formula Giusti Hayton adalah 500 mg/ 24 jam. Sama seperti Siprofloksasin, kenaikan SCr dan kejadian efek samping (diare headache, nausea) tidak teramati.

\section{Beta lactam}

Beta lactam memberikan efek bakterisidal tergantung waktu (Time Dependent killers). Penyesuaian dosis dilakukan dengan penurunan dosis dan mempertahankan interval pemberian obat untuk memaksimalkan konsentrasi plasma obat berada di atas MIC (Eyler dan Shvets, 2019).

Pada penelitian ini golongan Beta Lactam yang belum tepat penyesuaian dosis adalah Cefepim (Sefalosporin generasi keempat), Sefiksim (Sefalosporin generasi ketiga), Meropenem (Carbapenem) dan Ampisilin Sulbaktam (Penisilin).

Cefepim digunakan terbatas pada severe infeksi. Kurang lebih $85 \%$ obat utuh diekskresikan melalui ginjal dan dapat meningkatkan serum kreatinin pada penurunan fungsi ginjal. Efek samping yang muncul karena kelebihan dosis adalah nyeri perut dan gangguan Central Nerfous System, tetapi jarang terjadi (Kim dkk., 2012).

Pada penelitian ini Cefepim digunakan tidak tepat interval. Dosis Cefepim yang digunakn 1g/8 jam, melebihi dosis penyesuaian menurut pustaka yaitu 1-2 g/24 jam. Sedangkan dosis penyesuaian menurut Giusti Hayton adalah 200-750 mg/8 jam pada $\mathrm{CrCl} 25$ $\mathrm{ml} /$ menit. Efek samping yang teramati karena 
overdosis adalah kenaikan SCr dari 2,1 menjadi 2,9 mg/L dan menyebabkan severe depressive.

Meropenem merupakan antibiotik yang memiliki spektrum aktifitas yang luas (broad spectrum). Pada penelitan ini dosis meropenem tidak tepat dosis dan interval. Pada satu kasus ditemukan pemakaian dosis subterapetik, yaitu 1g/12 jam, dimana seharusnya diberikan 1-2 g / 8 jam pada $\mathrm{CrCl}>50 \mathrm{ml} /$ menit (Lacy dkk,2014) dan 650-1250 mg/8 jam menurut formula Giusti Hayton. Outcome clinic tidak tercapai ditandai dengan sepsis.

Ketidaktepatan pendosisan meropenem juga terjadi pada pasien dengan $\mathrm{CrCl} 35$ $\mathrm{ml} /$ menit. Ketidaktepatan ini disebabkan ketidaktepatan interval pemakaian. Demikian juga dengan ampisilin sulbaktam. Untuk sefiksim, terjadi ketidaktepatan dosis dan interval. Dosis yang digunakan dan dosis penyesuaian yang seharusnya diberikan (Tabel II). Efek samping yang terjadi karena kelebihan dosis ketiga obat tersebut adalah gangguan Central Nervus System seperti pusing dan seizure (Eyler dan Shvets, 2019). Pada penelitian ini efek samping tersebut tidak terjadi. Kenaikan SCr dari 1,2 menjadi 2,1 ml/menit terjadi pada pemakaian Meropenem.

\section{Diuretik}

Spironolakton merupakan diuretik hemat kalium yang harus digunakan dengan hati-hati karena dapat menyebabkan hiperkalemi (Ponticelli dkk., 2015). Pada penurunan fungsi ginjal, efek samping hiperkalemi tersebut dapat dihindari dengan penggunaan bersama tiazid, furosemide atau keduanya (Hartman, 2010). Menurut pustaka, pada $\mathrm{CrCl}<30 \mathrm{ml} /$ menit penggunaan obat ini sebaiknya dihindari (Lacy dkk, 2014). Pada penelitian ini efek samping hiperkalemi tidak terjadi karena digunakan bersama furosemid.

Manitol merupakan diuretic osmotic yang digunakan untuk menurunkan tekanan intra kranial. Penggunaan manitol pada penurunan fungsi ginjal dikontraindikasikan karena dapat meningkatkan kejadian Acute Kidney Injury (AKI)(Kim dkk., 2014). Pada penelitian ini penggunaan manitol tidak tepat. Kenaikan SCr tidak dapat dilaporkan karena belum ada data SCr setelah penggunaan obat ini.

\section{Sodium Fondaparinux}

Sodium Fondaparinux diekskresi melalui ginjal dengan $\mathrm{f}=77 \%$. Menurut pustaka, pada
GFR $<30 \mathrm{ml} /$ menit obat ini dikontraindikasikan (Lacy dkk, 2014 dan Golightly dkk, 2013). Dosis penyesuaian menurut Giusti Hayton adalah 1,1 mg/24 jam. Pada penelitian yang dilakukan Turpie, dkk (2008), pemberian fondaparinuks $1,5 \mathrm{mg} / 24$ jam pada pasien dengan $\mathrm{CrCl}$ 20-50 $\mathrm{mL} / \mathrm{min}$ dibandingkan dengan pemberian fondaparinuks $2,5 \mathrm{mg} / 24$ jam pada pasien dengan $\mathrm{CrCl}>50 \mathrm{~mL} / \mathrm{min}$ mempunyai konsentrasi plasma yang sama sehingga keamanan terhadap resiko pendarahan juga tidak berbeda. Pada penelitian ini, dosis fondaparinuks yang digunakan tidak tepat dosis (2,5 mg/24 jam). Tidak terjadi pendarahan pada overdosis ini karena digunakan jangka pendek (3 hari).

\section{Telbivudin}

Telbivudin diekskresi melalui ginjal dengan $\mathrm{f}=42 \%$. Penggunaan jangka panjang dengan dosis yang berlebih dapat meningkatkan resiko Chronic Kidney Disease (Gane dkk., 2014) Pada penelitian ini pemakaian telbivudin belum tepat interval. Dosis yang digunakan 800 mg/ 24 jam pada $\mathrm{CrCl} 37,8 \mathrm{ml} /$ menit. Dosis penyesuaian 600 mg/48 jam (Lacy dkk,2014 dan Golightly dkk, 2013), sedang dosis penyesuaian menurut formula Giusti Hayton 450 mg/24 jam.

\section{Loratadin tablet}

Loratadin diekskresi melalui ginjal dengan $\mathrm{f}=40 \%$. Pemakaian loratadin pada ginjal normal dibandingkan dengan penggunaan pada $\mathrm{CrCl}>30 \mathrm{ml} /$ menit dan pada $\mathrm{CrCl}<15$ $\mathrm{ml} /$ menit tidak berbeda signifikan pada pengamatan T1/2, Cmax dan tmax (Davila dkk, 2013). Dosis loratadin pada ginjal normal 10 mg/24 jam. Penggunaan pada geriatri dikehendaki dosis rendah karena sensitif terhadap efek samping pada Susunan Syaraf Pusat. ADR yang dapat muncul berupa pusing, mulut kering, mengantuk dan somnolence yang dapat menyebabkan jatuh (Coggins, 2013).

Pada penelitian ini loratadin digunakan tidak tepat interval, yaitu dosis $10 \mathrm{mg} / 12$ jam selama 3 hari. Tidak ditemukan ADR pada pemakaian jangka pendek ini.

\section{Hubungan ketepatan dosis dengan outcome clinic}

Persentase tepat dosis dengan outcome clinic tercapai sebesar $58 \%$ dan $14 \%$ tidak tercapai. Sedangkan persentase tidak tepat dosis dengan outcome clinic tercapai sebesar 19 
Tabel III. Hubungan Ketepatan Dosis dengan Outcome Clinic

\begin{tabular}{lcccc}
\hline \multirow{2}{*}{ Dosis penyesuaian } & \multicolumn{2}{c}{ Ketercapaian outcome clinic } & \multirow{2}{*}{ Jumlah (N) } & \multirow{2}{*}{ p } \\
\cline { 2 - 3 } & Tidak tercapai & tercapai & & \\
\hline Tidak tepat & 8 & 19 & 27 & \\
Tepat & 14 & 58 & 72 & 0.289 \\
Jumlah & 22 & 77 & 99 & \\
\hline
\end{tabular}

\% dan tidak tercapai 8\%. Data hubungan ketepatan dosis dengan outcome clinic (Tabel III).

Hasil uji statistik dengan Chi Square menunjukkan bahwa tidak terdapat hubungan signifikan antara ketepatan dosis penyesuaian ginjal pada penurunan fungsi ginjal pasien geriatri dengan outcome clinic $(\mathrm{p}=0,289)$.

Setiap obat mempunyai variabilitas yang besar antara kadar obat dalam plasma dengan respon pada masing-masing individu. Faktor obesitas atau kekurangan gizi dan adanya penyakit lain sangat mempengaruhi farmakokinetika obat dan respon klinik seperti gagal jantung (Flurie dkk, 2015.). Penelitian yang dilakukan oleh Praptiwi (2015) menunjukkan bahwa ketepatan dosis tidak berhubungan signifikan dengan outcome clinic tetapi konsultasi gizi mempengaruhi outcome clinic pada pasien DM tipe 2 geriatri dengan gangguan fungsi ginjal.

\section{KESIMPULAN}

Hampir semua pasien geriatri (99 \%) mendapatkan resep yang memerlukan penyesuaian dosis karena mengalami penurunan fungsi ginjal. Pada penelitian ini tidak terdapat hubungan antara kesesuaian dosis dengan outcome clinic $(\mathrm{p}=0.289)$. Peran Farmasi Klinik perlu ditingkatkan untuk mengawal pengobatan yang tepat dan aman bagi pasien.

\section{UCAPAN TERIMA KASIH}

Penulis mengucapkan terimakasih kepada Badan Pengembangan dan Pemberdayaan Sumber Daya Manusia Kesehatan- Kementerian Kesehatan Republik Indonesia sebagai penyandang dana dalam penelitian ini.

\section{DAFTAR PUSTAKA}

Alahdal, Abdulrahman M., and Elberry Ahmed A, 2012, Evaluation of Applying Drug Dose
Adjustment by Physicians in patients with Renal Impairment, Saudi Pharmaceutical Journal: SPJ 20, no. 3 (July 2012): 217-20 https://www.ncbi.nlm.nih.gov/pmc/arti cles/PMC3745053/ (diakses tanggal 26/6/2018)

BPS, 2017, Profil Lansia Provinsi Jawa Tengah 2017, Badan Pusat Statistik Provinsi Jawa Tengah Katalog 4104001.33 https://jateng.bps.go.id/publication/20 18/08/24/9cc4db415868cd91d614bbe 8/profil-lansia-provinsi-jawa-tengah2017.html (diakses tanggal 13-5-2019)

Chan, J., Bajnath, A., Fromkin, B., Haine, D., Paixao, R., Sandy, D., dkk., 2014. Ketorolac Prescribing Practices in an Acute Care Hospital and the Incidence of Acute Renal Failure. World Journal of Nephrology and Urology, 3: 113-117-117. https://www.wjnu.org/index.php/wjnu /article/view/169 (diakses tanggal 26/3/2019)

Coggins, M.D., 2013, Antihistamine Risks, URL: http://www.todaysgeriatricmedicine.co $\mathrm{m} /$ archive/0313p6.shtml (diakses tanggal 18/5/2019)

Cockcroft, D. W., and M. H. Gault, 1976, Prediction of Creatinine Clearance from Serum Creatinine, Nephron 16, no. 1 (1976): 31-41. https://doi.org/10.1159/000180580

Corsonello, Andrea, 2005, Concealed Renal Insufficiency and Adverse Drug Reactions in Elderly Hospitalized Patients, Archives of Internal Medicine 165, no. 7 (April 11, 2005):

790. https://doi.org/10.1001/archinte.165.7. 790

David, K; Nielsen, Marcy; Grundy, Paul, 2012, Integrated Comprehensive Medication Management to Optimize Patient Outcomes, Resource Guide, The Patient Centered Medical Home https://www.pcpcc.org/sites/default/fil 
es/media/medmanagement.pdf (diakses tanggal 13-5-2019)

Eyler, R.F. dan Shvets, K., 2019. Clinical Pharmacology of Antibiotics. Clinical Journal of the American Society of Nephrology, CJN.08140718. https://cjasn.asnjournals.org/content/e arly/2019/03/11/CJN.08140718

Flurie, R.W. dan Matzke, G.R., 2015. Drug Dosing in the Elderly with Chronic Kidney Disease

https://www.kidneynews.org/kidneynews/special-sections/geriatricnephrology/drug-dosing-in-the-elderlywith-chronic-kidney-disease 2.

Gane, E.J., Deray, G., Liaw, Y.-F., Lim, S.G., Lai,C.L., Rasenack, J., dkk., 2014. Telbivudine improves renal function in patients with chronic hepatitis B. Gastroenterology, 146: 138-146.e5 https://www.gastrojournal.org/article/ S0016-5085(13)01359-0/fulltext

Golightly, L., Teitelbaum, I., Kiser, T., Levin, D., dan Barber, G., 2013. Renal Pharmacotherapy, Dosage Adjusment of Medications Eliminated by The Kidneys. Springer Science Business Media, New York

Hartmann, B., Czock, D., dan Keller, F., 2010, Drug Therapy in Patients with Chronic Renal Failure. Deutsches Aerzteblatt Online,

https://www.aerzteblatt.de/10.3238/ar ztebl.2010.0647

Heaf, James, 2014, Metformin in Chronic Kidney Disease: Time for a Rethink. Accessed March 26, 2019. https://www.ncbi.nlm.nih.gov/pmc/arti cles/PMC4079480/

Hidayat, Mahirsyah WWT, 2016, Hubungan Antara Ketepatan Penggunaan Obat Pada Pasien Usia Lanjut Terhadap Efek Samping Dan Lama Perawatan Di Bangsal Rawat Inap RSUP Dr Kariadi Semarang, Magister Farmasi Klinik UGM

Kim, M.Y., Park, J.H., Kang, N.R., Jang, H.R., Lee, J.E., Huh, W., dkk., 2014. Increased risk of acute kidney injury associated with higher infusion rate of mannitol in patients with intracranial hemorrhage: Clinical article. Journal of Neurosurgery, 120: 1340-1348. https://thejns.org/view/journals/jneurosurg/1
Kim, S.Y., Lee, I.S., Park, S.L., dan Lee, J., 2012 Cefepime Neurotoxicity in Patients with Renal Insufficiency. Annals of Rehabilitation Medicine, 36: 159-162. https://www.ncbi.nlm.nih.gov/pmc/arti cles/PMC3309312/20/6/articlep1340.xml

Lacy, C. F., Armstrong, L. L., Goldman, M. P., Lance, L. L., 2014, Drug Information Handbook with International Trade Names Index, 22 Eds, American Pharmacist Assosiation, Lexicom, Hudson, $\mathrm{O}$

Lea-Henry, T.N., Carland, J.E., Stocker, S.L.,

Sevastos, J., dan Roberts, D.M., 2018, Clinical Pharmacokinetics in Kidney Disease: Fundamental Principles. Clinical Journal of the American Society of Nephrology, 13: 1085-1095.

https://cjasn.asnjournals.org/content/1 3/7/1085

Maher, Robert L, Joseph, Hanlon; Emily R Hajjar, 2014, Clinical Consequences of Polypharmacy in Elderly, Expert Opinion on Drug Safety 13, no. 1 (January 2014): 57-65. https://doi.org/10.1517/14740338.201 3.827660

Mallappallil, M., Friedman, E.A., Delano, B.G., McFarlane, S.I., dan Salifu, M.O., 2014. Chronic kidney disease in the elderly: evaluation and management, Clinical practice (London, England), 11: 525-535. https://www.ncbi.nlm.nih.gov/pmc/ articles/PMC4291282/

Manlucu, J., Tonelli, M., Ray, J.G., Papaioannou, A., Youssef, G., Thiessen- Philbrook, H.R., dkk., 2005. Dose-reducing $\mathrm{H} 2$ receptor antagonists in the presence of low glomerular filtration rate: a systematic review of the evidence. Nephrology Dialysis Transplantation, 20: 2376-2384. https://academic.oup.com/ndt/article /20/11/2376/1829287

Montañés-Pauls, B., Sáez-Lleó, C., danMartínezRomero, G., 2009. Adjusting the dosage of medication in institutionalised elderly patients with renal failure. Farmacia Hospitalaria (English Edition), 33: 43-47. https://linkinghub.elsevier.com/retri eve/pii/S2173508509700681(diakses tanggal 3-1-2019)

Nace, David K, Nielsen,M, Grundy,P, 2012, Integrated Comprehensive Medication 
Management to Optimize Patient Outcomes, Resource Guide, The Patient Centered Medical Home https://www.pcpcc.org/sites/defaul/ files/media/medmanagement.pdf (diakses tanggal 13-5-2019)

Ponticelli, C., Sala, G., dan Glassock, R.J., 2015. Drug management in the elderly adult with chronic kidney disease: a review for the primary care physician. Mayo Clinic Proceedings, 90: 633-645.
Praptiwi.,2015, Evaluasi Pendosisan Antidiabetika Oral Pada Pasien DM Tipe 2 Geriatri Dengan Gangguan Fungsi Ginjal Rawat Jalan Di RSUD Sleman Yogyakarta, Magister Farmasi Klinik UGM

Shargel, L; Wu-Pong, S., Yu A,BC, 2012, Aplied Biopharmaceutics \& Pharmacokinetics, 5 edition, Mc Graw Hills

Wahyono,D,2012, Farmakokinetika Klinik, Gadjah Mada University Press, p.70-76. 